\title{
Kang Pisman (Reduce, Reuse, and Recycle) Program Implementation Strategy for Waste Management in Sukamiskin Village Bandung City
}

\author{
Rosalinda Fatrianingsih ${ }^{1}$, Laksmi Fitriani ${ }^{2}$, Ely Sufianti ${ }^{3}$ \\ Politeknik STIA LAN Bandung, Indonesia ${ }^{123}$ \\ \{rosalindaf63@gmail.com¹, laksmi.fitriani@poltek.stialanbandung.ac.id², \\ ely.sufianti@poltekstialanbandung.ac.id ${ }^{3}$ \}
}

\begin{abstract}
Kang Pisman program aims to involve the community to manage waste started from households by reducing and handling in order to minimize waste they generate. The problems faced during the implementation are: low of public awareness and lack of waste management facilities in several RWs (neighborhood association). The purpose of this study is to analyze the implementation of the Kang Pisman program in Sukamiskin Village and formulate the strategy to overcome the problems. This study uses a qualitative method. Formulating strategy uses SWOT analysis. The result shows that the implementation of the Kang Pisman program is not optimal due to the low awareness of the community to sort waste, and also lack of waste management facilities in several RWs especially the land availability. To overcome this problem, the strategies propose are: intention of socialization, making waste management books, making infographics, strengthening local regulations on waste management and building collaboration between RWs.
\end{abstract}

Keywords: Strategy Implementation; Waste Management Strategy Implementation; Waste Management

\section{Introduction}

Garbage is one of the problems faced by developing countries, including Indonesia. Waste generated from human activities and/or natural processes in solid form [1]. Waste is residual material from activities carried out by humans which will later be disposed of because it is no longer used. Almost all human activities have the potential to produce waste. Data from the Ministry of Environment and Forestry (KLHK) shows that Indonesia produced around 67.8 million tons of waste in 2020. As time goes by, and population growth, the increase in waste piles will also continue increase every single year. As the result, if there are no waste management efforts, waste can pollute the environment, disrupt health, and also disrupt the stability of ecosystems in certain areas.

Waste management is a comprehensive effort to deal with waste generated from various human activities. Waste management is started by processing waste from its source, which is carried out individually and collectively. Within the sorting process, it may some waste can still be utilized. The purpose of this waste management is to reduce waste that will be transported to final landfill site (TPA). Managing waste, especially in urban areas, is very difficult to do and is a serious problem because of the various challenges faced. The main reason for this 
unresolved waste problem is that the community's ability to manage waste in their environment is still weak. Community awareness and cooperation are needed to solve the waste problem.

The city of Bandung is one of the big cities in Indonesia which still has problems in waste management. Based on data from the National Waste Management Information System (SIPSN). The city of Bandung produces 1,628.08 tons of waste in one day and 594,249 tons in one year in 2020. Most of the waste in Bandung City comes from household, reaching 63.16\% of the total average daily waste production. The rest comes from offices $4.21 \%$, commerce $6.31 \%$, market $10.53 \%$, public facilities $14.02 \%$ and others $1.77 \%$. The largest source is generated by household waste. The city of Bandung produces 976.85 tons of household waste in one day from 670,159 households in the city of Bandung (Central Bureau of Statistics (BPS) West Java, 2020).

Dealing with the waste problem, the Bandung City government launched a waste management program in 2018, namely Kang Pisman. This term comes from reduce, reuse, and recycle, that literally familiar for the Bandung City people. Kang Pisman was created because of the increasingly serious waste problem and also the lack of awareness of Bandung City people towards waste management. The legal basis for the Kang Pisman program is the Bandung City Regional Regulation No. 09 of 2018 concerning Waste Management. The Kang Pisman program is a movement that making collaboration between the government, citizens, the private sector and other parties in building a new civilization of more advanced waste management.

Sukamiskin is one of the urban villages (kelurahan) that has implemented the Kang Pisman program. Previously, the Sukamiskin people disposed their waste without sorting organic and inorganic waste. This can have a negative impact on the environment and can contaminate soil, air and water. If this waste problem continues and is not managed properly, the waste problem become worst. This condition is also related to the cost: the more waste, the higher the environmental maintenance cost. Furthermore, implementing waste management needs community participation. The more people participate, the less waste goes to the landfill site.

The purpose of this study is identifying the implementation of the Kang Pisman program and formulate strategies for increase the effectiveness of Kang Pisman Program in Sukamiskin Village.

\section{Concepts and Theory}

Waste management needs collaboration of all stakeholders, through participative ways. The government, in fact, fails in handling municipal waste in his own, therefore, it needs participation of all stakeholders. The government, society, private sectors, colleges, media should involve. The actor from each party has to be realize that waste problem needs their intention to be solved, otherwise it is getting worse. Each of them has role in participation process by contributing something that is needed for reach the goal, minimizing waste to landfill. In order to increase people participation in waste management, strategy must be built.

Strategy is a process of determining the plans of top leaders that focus on the long-term goals of the organization, accompanied by the preparation of a method or effort on how to achieve these goals [2]. A strategy is a unified, comprehensive, and integrated plan that relates the strategic advantages of the firm to the challenges of the environment. It is designed to ensure that the basic objectives of the enterprise are achieved through proper execution by the organization [3]. Therefore, it can be explained that strategy is a planning formulation that is 
prepared as an effort to achieve the goals to be achieved by an organization which is described in activities, programs and policies.

Public policy is a number of government activities to solve problems in the community, either directly or through various institutions that affect people's lives[4]. When the government makes a decision, it must have clear objectives, and public policy includes all government actions, so it is not merely a statement of the will of the government or government officials [5]. Public policy is whatever the government chooses to do or not to do. If the government chooses to do something then there must be a goal and the state's policy must include all government actions, not merely a statement of the government's or its officials' wishes.

Policy implementation is a very important stage in the overall policy structure, because it is the process that determines the level of success or achievement of the objectives of the substance of the policy. Chief J.O. Udoji [8] states that "policy implementation is something important, perhaps even more important than policy making". A policy becomes just a plan or a "meaningless document"[5] if it is not implemented.

One of Policy Implementation Models was built by Van Meter and Van Horn [6]. This model explains that the success of a policy is influenced and determined by many factors, and each of these factors is interconnected with one another.

There are six variables that influence the success of policy implementation:

a. Policy standards and objectives. Policy standards and objectives are one of the factors that influence the success of policy performance. Therefore, policy objectives and indicators of success need to be clear and measurable.

b. Resources. The success of policy implementation highly depends on the ability to use the available resources, both human and non-human resources to support the smooth implementation of policies. Resources are also the key to running an organization.

c. Inter-organizational relations. Implementing policy needs communication and coordination with other agencies, and the standard goals must be understood by individuals (implementors) indeed. Communication and coordination in the delivery of information to policy implementers regarding the standards and objectives must be consistent and uniform from various sources of information [7].

d. Characteristics of implementors. Other supporting factors that can determine the success of policy implementation, namely the characteristics of implementers who implement policies. This is related to the policy context that will be implemented in several policies requiring strict and disciplined policy implementers.

e. Social, political, and economic conditions. External environmental conditions such as social, political, and economic factors contribute to the success of policy implementation. With a conducive environment, policy implementation can be carried out properly. On the other hand, if the surrounding environment is not conducive, it will be the cause of the failure of policy implementation performance.

f. Implementor Disposition. According to Van Metter and Van Horn [8], acceptance or rejection of policy implementing agents greatly affects the success or failure of public policy implementation. With the attitude of acceptance from the implementer, the policy can be carried out in accordance with the goals and objectives to be achieved, then the success of policy implementation can be achieved properly. On the other hand, if the policy implementer implements it with an attitude of rejection, it will hinder the success of policy implementation. 


\section{Methods}

This study uses qualitative approach. The data and information were obtained through interviews, observations and document studies. Data verification is done by data triangulation to check the validity of the data. In conducting the research, the researcher chose the locus in Sukamiskin Village. Data and information were analyzed by Van Meter and Van Horn policy implementation model to explore the implementation of the Kang Pisman program in Sukamiskin Village. Furthermore, formulate strategies was done by SWOT analysis to identify the internal and external environment as well as opportunities and threats.

\section{Result and Discussion}

\subsection{Policy Implementation}

To explore the policy implementation of the Kang Pisman program in Sukamiskin Village, this study uses the analytical tool, namely Van Meter and Van Horn policy implementation model. This model suggests six factors that must be considered in achieving success: (1) Standards and policy objectives; (2) Resources; (3) Relationships between organizations; (4) Characteristics of implementers; (5) Social, political, and economic conditions; and (6) Implementor Disposition. By using this model, this study describes the condition of waste management in the Sukamiskin Village and identify the supporting and constraining factors of waste management in the Sukamiskin Village.

\section{a. Standards and Policy Objectives}

The local regulation behind the Kang Pisman program is the Bandung City Regional Regulation Number 9 of 2018 concerning Waste Management. This regulation was made with the goal solving the waste problem that occurred in the city of Bandung. The purpose of the waste management policy is to reduce the volume of waste in the city of Bandung through reduce and handle waste. The purpose of the waste management policy is also to involve the people in Bandung City to start separating waste from their homes. The regulation also emphasizes the management of the source so as to minimize the waste that comes out of the household.

The success standard of the Bandung City Regional Regulation Number 9 of 2018 concerning Waste Management is that every person/community aware and comply this policy then start managing waste. To achieve the success of this policy requires the cooperation of all parties, not only the government but also the people who play a major role in efforts to reduce the volume of waste. The Bandung City Major claims for the achievement. After this regulation is implemented, the waste goes to final landfill area decrease from 7.060,80 Tons in one day in 2018[9] become 1.533,65 Tons in one day in 2020[10]. Furthermore, there are 143 urban villages implement this policy through establish 467 Waste bank in 2020[11].

\section{b. Resources}

The human resources deployed in the Kang Pisman program in the Sukamiskin sub-district are sufficient to run this program. The human resources for implementing the kang pisman program are considered to be good enough in socializing and checking to the public whether they have managed and sorted waste properly or not, which is done by door to door. For the garbage officers in the neighborhood association (RWs), it is also sufficient to transport garbage 
and also to remind the public to sort and not mix the sorted waste again. The financial resources used in the implementation of the Kang Pisman program come from the Bandung City Regional Revenue and Expenditure Budget. Based on information from informants, the budget was used according to needs and there were no constraints in terms of financing. The allocated budget is used to provide facilities for the community and waste management officers to sort waste and manage waste.

The facility resources or facilities and infrastructure provided in carrying out the Kang Pisman program in the form of trash cans, garbage transport vehicles are sufficient, for organic waste management sites and inorganic waste collection sites also exist in several RWs, but of the 17 RWs that already have management sites are RW 1, 2, 6, 7, 8, 9, 10, 13, and 14 and the rest, that are RW 3, 4, 5, 11, 12, 15, 16 and 17 do not yet have their own waste management facilities because they have limited land.

Table 1. Data on Garbage Transport Facilities in Sukamiskin Village 2020

\begin{tabular}{|c|c|c|}
\hline No & Garbage Transportation Facilities & Number of units \\
\hline 1 & Motorbike & 19 \\
\hline 2 & Cart & 10 \\
\hline 3 & Garbage Pushcart & 6 \\
\hline 4 & Pickup car & 2 \\
\hline
\end{tabular}

\section{c. Inter-organizational relations}

The relationship between organizations is carried out by communication and coordination between the stakeholders involved. The stakeholders are the Bandung City Environment Service, the Bandung City Food and Agriculture Security Service and the Sukamiskin Village. In terms of communication, the relationship between the three goes well in accordance with the program directed by the city government. Coordination among them is carried out once every three months (quarterly) to evaluate the achievements of the Kang Pisman program.

\section{d. Characteristics of implementors}

The implementors of the Kang Pisman program run the program in accordance with existing policies and tasks, and already done with high discipline because they are continuously monitored by the kelurahan and by the companion team. The Kang Pisman program has been carried out properly in accordance with the direction of the city government. With the discipline they do, there are already several RWs that have started to optimize their use of waste, although not all people participate.

\section{e. Social, political, and economic conditions}

The external environment is quite conducive, where the community supports the Kang Pisman program, even though it is not $100 \%$ of the people implement it. Community participation in carrying out waste management in Sukamiskin Village is still low, it is 5.694 out of 1.920 households $(33,7 \%)$ that have already doing waste separation. Table 2 describes more detail about achievement of waste sorting for each RW in Sukamiskin Village: 
Table 2. The Number of Household implement Waste Separation for each RW in Sukamiskin

\begin{tabular}{|c|c|c|}
\hline \multicolumn{3}{|c|}{ Village } \\
\hline RW & $\begin{array}{c}\text { Number of } \\
\text { Households }\end{array}$ & $\begin{array}{c}\text { Number of } \\
\text { Households }\end{array}$ \\
\hline RW 1 & 300 & 64 \\
\hline RW 2 & 400 & 213 \\
\hline RW 3 & 116 & 16 \\
\hline RW 4 & 180 & 45 \\
\hline RW 5 & 470 & 264 \\
\hline RW 6 & 250 & 59 \\
\hline RW 7 & 175 & 87 \\
\hline RW 8 & 300 & 154 \\
\hline RW 9 & 316 & 176 \\
\hline RW 10 & 307 & 41 \\
\hline RW 11 & 273 & 220 \\
\hline RW 12 & 360 & 75 \\
\hline RW 13 & 683 & 79 \\
\hline RW 14 & 412 & 63 \\
\hline RW 15 & 600 & 125 \\
\hline RW 16 & 300 & 40 \\
\hline RW 17 & 252 & 199 \\
\hline Total & 5694 & 1920 \\
\hline
\end{tabular}

Note: Population update as of August 2020 and Monitoring Results April-December 2020 Source: Sukamiskin RTPS Study 2020

From the economic side, waste has economic value for the community. Organic waste could be processed to be fertilizer that has a selling value. Meanwhile, inorganic waste can also be reused or sell it to collector. It is also can be reused with different functions or can be made into crafts such as bags so that it can be sold. In Sukamiskin, some waste is processed to be handicrafts such as bag, stationary, or artificial flower.

\section{f. Implementor Disposition}

The Kang Pisman program implementer in Sukamiskin Village already understands the Kang Pisman policies and programs that are being implemented, there is no refusal to implement the Kang Pisman program. So that the kang pisman program can run in accordance with the aims and objectives of the policy to be achieved. In addition, the response of the implementers to the waste management policy was quite good, because the implementers realized that complying with the Bandung City Regional Regulation Number 9 of 2018 concerning Waste Management is their responsibility.

\subsection{Building Strategy}

a. Determining Strategy

After analyze the Kang Pisman program in Sukamiskin Village using policy implementation model, then a SWOT analysis will be carried out. SWOT analysis is the identification of various factors systematically in order to formulate a strategy[12]. By mapping internal factors and external factors consisting of strenghts, weaknes, opportunity, and threats. SWOT analysis is an effective analytical tool in mapping out strategies for problems that occur on a program. With a SWOT analysis, it is possible to identify strategic issues or factors that need to be developed in order to improve waste management in Sukamiskin Village. 
The following are the issues regarding strenghts, weaknes, opportunity, and threats:

1. Strenghts

a. Regional Regulation on waste management Number 9 of 2018.

b. Facilities and infrastructure in the form of transportation equipment and trash cans for sorting.

c. The commitment of program implementers is quite strong.

2. Weaknes

a. There is no land to manage waste.

b. Not even distribution of waste processing sites in all RWs.

c. There are no sanctions against people who do not sort waste.

3. Opportunity

a. Garbage recycling business.

b. Economic value of waste.

c. Waste management technology.

4. Threats

a. Low public awareness.

b. Waste production continues increases.

c. The organic and inorganic waste has not been separated.

After determining the issues of strengths, weaknesses, opportunities, and threats for Kang Pisman program, the next step is build the SWOT matrix which is carried out by comparing internal and external factors. This step aims to determine alternative strategies to overcome the obstacles that occur during the program implementation. The SWOT matrix consists of four combined strategies between internal and external factors, namely SO strategy, ST strategy, WO strategy, and WT strategy.

The strategies are:

1. SO Strategies

a. Optimizing organic waste management.

b. Taking care of the garbage collection equipment so that it can last a long time and optimizing the use of trash bins for sorting.

c. Improving waste technology to be more modern.

2. ST Strategies

a. Optimizing socialization to invite people to start managing waste.

b. Create infographics.

3. WO Strategies

a. Increase socialization on how waste can be a business opportunity that has economic value.

b. Collaborating with several RWs that already have waste processing sites.

4. WT Strategies

a. Routine socialization to increase community participation.

b. Create a waste sorting book.

\section{b. Analysing Internal and External Factors}

This analysis is carried out by assigning a weighting and rating to each strategic factor of the internal and external environment. Internal Factor Analysis (KAFI) was conducted to find out the possible alternatives of existing strengths and weaknesses. While External Factor Analysis (KAFE) was carried out to find out alternative possible opportunities and threats. 
The weighting is done by giving a scale ranging from 1.0 (most important) to 0.0 (not important). While the rating is given based on the level of influence of each factor on the strategy, the ratings are given, among others:

4: very good influence

3: good influence

2: enough influence

1: ittle influence

Table 3. Internal Factor Analysis (KAFI)

\begin{tabular}{|c|c|c|c|c|}
\hline No. & Internal Strategic Factors & Weight & Rating & $\begin{array}{l}\text { Score } \\
(\mathbf{W} \times R)\end{array}$ \\
\hline 1 & 2 & 3 & 4 & 5 \\
\hline \multicolumn{5}{|c|}{ Strength } \\
\hline 1 & $\begin{array}{l}\text { Regional Regulation on waste } \\
\text { management Number } 9 \text { of } 2018 \text {. }\end{array}$ & 0,20 & 4 & 0,80 \\
\hline 2 & $\begin{array}{l}\text { Facilities and infrastructure in the } \\
\text { form of transportation equipment and } \\
\text { trash cans for sorting. }\end{array}$ & 0,15 & 3 & 0,45 \\
\hline 3 & $\begin{array}{l}\text { The commitment of program } \\
\text { implementers is quite strong. }\end{array}$ & 0,15 & 4 & 0,60 \\
\hline \multicolumn{2}{|r|}{ Total Strength } & 0,50 & & 1,85 \\
\hline \multicolumn{5}{|c|}{ Wekness } \\
\hline 1 & There is no land to manage waste. & 0,10 & 2 & 0,20 \\
\hline 2 & $\begin{array}{l}\text { Not even distribution of waste } \\
\text { processing sites in all RWs. }\end{array}$ & 0,15 & 3 & 0,45 \\
\hline 3 & $\begin{array}{l}\text { There are no sanctions against people } \\
\text { who do not sort waste. }\end{array}$ & 0,25 & 4 & 1,0 \\
\hline \multicolumn{2}{|r|}{ Total Wekness } & 0,50 & & 1,65 \\
\hline \multicolumn{2}{|r|}{ Total } & 1,00 & & \\
\hline
\end{tabular}

Tabel 4. Conclusion of External Factor Analysis (KAFE)

\begin{tabular}{|c|c|c|c|c|}
\hline No. & External Strategy Factors & Weight & Rating & $\begin{array}{r}\text { Skor } \\
(\mathbf{W x R})\end{array}$ \\
\hline 1 & 2 & 3 & 4 & 5 \\
\hline \multicolumn{5}{|c|}{ Opportunity } \\
\hline 1 & Garbage recycling business. & 0,20 & 4 & 0,80 \\
\hline 2 & $\begin{array}{l}\text { Economic value from managing } \\
\text { waste. }\end{array}$ & 0,20 & 3 & 0,60 \\
\hline 3 & Waste management technology. & 0,10 & 2 & 0,20 \\
\hline & Total Opportunity & 0,50 & & 1,60 \\
\hline \multicolumn{5}{|c|}{ Threat } \\
\hline 1 & Low public awareness. & 0,20 & 4 & 0,80 \\
\hline 2 & $\begin{array}{l}\text { Waste production continues to } \\
\text { increase. }\end{array}$ & 0,15 & 4 & 0,60 \\
\hline
\end{tabular}




\begin{tabular}{|c|l|c|c|c|}
\hline 3 & $\begin{array}{l}\text { The organic and inorganic waste has } \\
\text { not been separated. }\end{array}$ & 0,15 & 3 & 0,45 \\
\hline Total Threat & 0,50 & & 1,75 \\
\hline Total & 1,00 & & \\
\hline
\end{tabular}

\section{a. Cartesian Diagram SWOT Analysis}

After determining the number of scores from internal and external factors, the next step is quadrant analysis that can be described in a SWOT diagram. To find the coordinates $(\mathrm{x}, \mathrm{y})$ used the following formula:

- Internal factors analysis ; External factor analysis

- $\quad \frac{\text { Total strength score-Total weakness score }}{2} ; \frac{\text { Total opportunity score-Total threat score }}{2}$

- $\quad \frac{S-W}{2} ; \frac{O-T}{2}$

- $\frac{1,85-1,65}{2} ; \frac{1,60-1,75}{2}$

- 0,$10 ;-0,08$

The coordinates of the point are at $(0,10 ;-0,08)$

Furthermore, after the $\mathrm{x}$ and $\mathrm{y}$ coordinates have been found, then they are entered into the Cartesian SWOT diagram

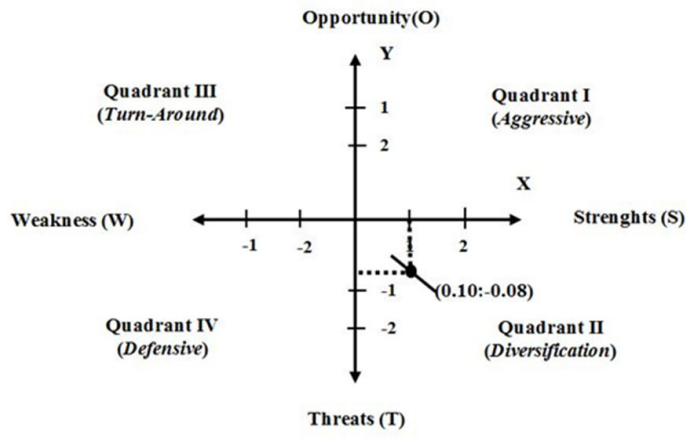

Fig 1. Cartesian SWOT Chart Results

Figures 1 shows that the strategy for implementing the Kang Pisman program in Sukamiskin Village is in Quadrant II position which is the diversification strategy. In this position, the Kang Pisman program strategy in Sukamiskin Village faces various threats that can become weaknesses in its implementation, but Sukamiskin Village still has internal strengths.

\section{Conclusion}

The implementation of the Kang Pisman Program in Waste Management in Sukamiskin Village Bandung City has not been optimal. This is caused by several factors, those are: low 
public awareness to manage waste, which many people still ignore, and several RWs in Sukamiskin Sub-district still do not have a management area. So that waste management in some of these RWs is not optimal because they do not have processing site.

Analysis of internal factors and external factors using SWOT analysis results in the strategy of the Kang Pisman program in Sukamiskin Village faces various threats that can be a weakness of the, but Sukamiskin Village also still has internal strengths to prevent these threats from becoming weaknesses in the implementation of the Kang Pisman program. The strategies are optimizing socialization to invite people to start managing waste and creating infographics to increase the people understanding about waste management.

\section{Recommendation}

Suggestions or recommendations proposed by this study to optimizing socialization are:

a. Making a Waste Management Book for all communities in Sukamiskin Village, with this book it can slightly force the community to start managing waste, hope by over time the community will become accustomed to managing waste.

b. Routine socialization to increase community participation, with continuous socialization, it is hoped that the community will understand more about the impacts caused by waste if it is not managed properly.

c. Creating infographics, share infographics, so that communication about the program of Kang Pisman can be delivered in a shorter and easier to build manner.

d. Strengthening Bandung City Regional Regulation Number 9 of 2018 concerning Waste Management. This can be done by requiring every community to start managing waste and disposing of waste according to its type, which is done by regulating regulations related to sanctions or actions to people who do not sort.

e. Build collaboration among RWs that do not have waste management facilities and several RWs that already have waste processing sites. So that waste in several RWs that do not have land to manage waste can be managed optimally.

\section{References}

[1] Peraturan Daerah Kota Bandung Nomor 9 Tahun 2018 Tentang Pengelolaan Sampah

[2] Umar, Hussein. Desain Penelitian Manajemen Strategik. Jakarta: Rajawali Press (2010)

[3] Glueck, W.F., \& Jauch, L.R. Strategic Management and Business Policy. New York: McGraw-Hill (1984)

[4] Tangkilisan, Hesel Nogi S dan Saputro, Hadi S. Kebijakan Publik Yang Membumi : Konsep, Strategi Dan Kasus. Jakarta: Lukman (2003)

[5] Pasolong, Harbani. Kepemimpinan Birokrasi. Bandung: Alfabeta (2008)

[6] Abidin, Said Zainal. Kebijakan Publik. Jakarta: Yayasan Pancur Siwah (2004)

[7] Subarsono, A. G. Analisis Kebijakan Publik: Konsep, Teori Dan Aplikasi. Yogyakarta: Pustaka Pelajar (2012)

[8] Agustino, Leo. Politik Dan Kebijakan Publik. Bandung: AIPI Bandung dan Puslit KP2W Lemlit Unpad (2006)

[9] Provinsi Jawa Barat Dalam Angka 2020

[10] Provinsi Jawa Barat Dalam Angka 2021

[11] Humas Bandung,https://humas.bandung.go.id/layanan/143-kawasan-bebas-sampah-dan-467-banksampah-dukung-kang-pisman (2020)

[12] Rangkuti, Freddy. Analisis SWOT Teknik Membedah Kasus Bisnis. Jakarta: Gramedia Pustaka Utama (2013) 